Article

\title{
Development of a New Arylamination Reaction Catalyzed by Polymer Bound 1,3-(Bisbenzimidazolyl) Benzene Co(II) Complex and Generation of Bioactive Adamanate Amines
}

\author{
Baburajeev Chumadathil Pookunoth ${ }^{1,+}$, Shilpa Eshwar Rao ${ }^{1,2,+}$, \\ Suresha Nayakanahundi Deveshegowda ${ }^{3}$, Prashant Kashinath Metri ${ }^{3}$, \\ Kashifa Fazl-Ur-Rahman ${ }^{1}$, Ganga Periyasamy ${ }^{1}$, Gayathri Virupaiah ${ }^{1,4}$, Babu Shubha Priya ${ }^{3}$, \\ Vijay Pandey ${ }^{5}$, Peter E. Lobie ${ }^{5,6, *}$, Rangappa Knchugarakoppal Subbegowda ${ }^{7, *}$ and \\ Basappa 1,3,*(D) \\ 1 Department of Chemistry, Central College Campus, Bangalore University, \\ Bangalore 560001, Karnataka, India; baburajeevnambiar@gmail.com (B.C.P.); \\ shilpa.gaikwad1989@gmail.com (S.E.R.); kashifaf07@gmail.com (K.F.-U.-R.); \\ ganga.periyasamy@gmail.com (G.P.); gayathritvr@yahoo.co.in (G.V.) \\ 2 Department of Inorganic and Physical Chemistry, Indian Institute of Science, \\ Bangalore 560012, Karnataka, India \\ 3 Laboratory of Chemical Biology, Department of Studies in Organic Chemistry, University of Mysore, \\ Manasagangotri, Mysore 570006, Karnataka, India; sureshand92@gmail.com (S.N.D.); \\ prashant.metri@gmail.com (P.K.M.); priyabs_chem@yahoo.com (B.S.P.) \\ Department of Chemistry, Bengaluru City University, Bangalore 560001, Karnataka, India \\ 5 Tsinghua Berkeley Shenzhen Institute, Tsinghua Shenzhen International Graduate School, \\ Shenzhen 518055, China; vijay.pandey@sz.tsinghua.edu.cn \\ 6 Shenzhen Bay Laboratory, Shenzhen 518055, China \\ 7 Institution of Excellence, Vijnana Bhavan, University of Mysore, Mysore 570005, Karnataka, India \\ * Correspondence: pelobie@sz.tsinghua.edu.cn (P.E.L.); rangappaks@chemistry.uni-mysore.ac.in (R.K.S.); \\ salundibasappa@gmail.com (B.); Tel.: +91-821-241-9428 (R.K.S.); +91-9481200076 (B.) \\ + These authors contributed equally.
}

Received: 10 October 2020; Accepted: 29 October 2020; Published: 13 November 2020

check for updates

\begin{abstract}
We herein report the preparation and characterization of an inexpensive polymer supported 1,3-bis(benzimidazolyl)benzeneCo(II) complex [PS-Co(BBZN)Cl $l_{2}$ as a catalyst by using the polymer (divinylbenzene cross-linked chloromethylated polystyrene), on which 1,3-bis(benzimidazolyl) benzeneCo(II) complex (PS-Co(BBZN)Cl $\mathrm{Cl}_{2}$ ) has been immobilized. This'catalyst was employed to develop arylamination reaction and robustness of the same reaction was demonstrated by synthesizing various bioactive adamantanyl-tethered-biphenylamines. Our synthetic methodology was much improved than reported methods due to the use of an inexpensive and recyclable catalyst.
\end{abstract}

Keywords: arylamination reactions; adamantanyl-tethered-biphenylamines; polymer-supported catalyst; cobalt complex; Buchwald-Hartwig reaction

\section{Introduction}

Transition metal-catalyzed cross-coupling reactions between aryl halides and primary/secondary amines to obtain aminated aryl compounds has been an area of interest due to the wide applications of arylamines in the synthetics and pharmaceutical industries [1-5]. In this direction, the BuchwaldHartwig cross-coupling reaction was performed by using transition metal catalysts, ligands and bases 
with substrates to obtain the desired arylamine products [6-8]. The disadvantage of this reaction is the use of expensive catalysts, which offers the chemist the opportunity to discover cheaper, reusable catalysts to drive the arylamination reactions. Inspired by major developments in cobalt-catalyzed arylamination reactions, we developed a complementary method to perform an arylamination reaction using cobalt as a metal catalyst [9-11]

In addition, benzimidazole ligand coordinated metal complexes are widely used as catalysts in arylamination reactions [12]. Since these catalysts were found to be less hydrophobic, immobilization of such metal complexes with polymer support was observed to be stable, selective, and recyclable, attributed to the steric, electrostatic, hydrophobic and conformational effects of the polymer support [13]. Hence, several reports pertaining to the synthesis of arylamines using polymer-supported transition metal complexes are found [14-16]. Specifically, chloromethylated polystyrene cross-linked with divinyl-benzene was employed as a macromolecular support to perform the arylamination reactions [17-22].

In medicinal chemistry, an adamantane-coupled bicyclical core structure was used as an important pharmacophore, which was inserted in many drugs [23]. Hence, the adamantane structure was recognized as a readily available "liphophilic bullet" for providing critical liphophilicity to known pharmacophoric units. Given the remarkable importance of adamantane chemistry, we recently reported the synthesis and biology of adamantyl-tethered biphenylic compounds as potent anticancer agents [24]. In our continued efforts to synthesize newer bioactive agents [25-31], we herein report a practical, economically feasible and efficient arylamination reaction using polymer-supported 1,3-bis(benzimidazolyl)benzeneCo(II) complex ( $\mathrm{PS}-\mathrm{Co}(\mathrm{BBZN}) \mathrm{Cl}_{2}$ ) as a catalyst. Interestingly, the recovered (PS-Co( $\left.\mathrm{BBZN}) \mathrm{Cl}_{2}\right)$ could be reused three times without a significant loss of activity.

\section{Results}

\subsection{Chemistry of Catalyst Design and Method Development}

We initially synthesized polymer-supported 1,3-bis(benzimidazolyl)benzeneCo(II) complex $\left[\mathrm{PS}-\mathrm{Co}\left(\mathrm{BBZN}^{\mathrm{C}} \mathrm{Cl}_{2}\right]\right.$ as shown in Scheme 1.

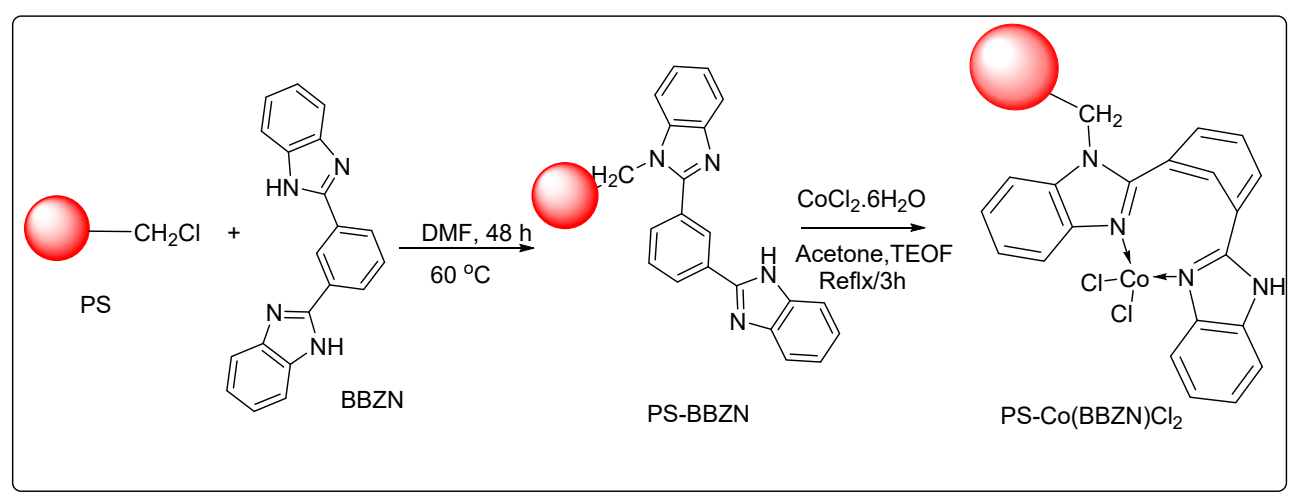

Scheme 1. Schematic representation to show synthesis of $\mathrm{PS}-\mathrm{Co}(\mathrm{BBZN}) \mathrm{Cl}_{2}$.

For this, 1, 3-bis(benzimidazolyl)benzene was treated with chloromethylated polystyrene divinylbenzene and followed by the addition of cobalt chloride. The obtained PS-Co (BBZN) $\mathrm{Cl}_{2}$ was characterized by analytical techniques including CHNS, UV-Vis, FT-IR, SEM-EDX and TGA as presented in supporting information (Figure 1, Supplementary SI-02). Based on N\% and Co $\%$ obtained through elemental and metal ion analysis, the complex formed on the polymer support was about 0.0053 moles per $1 \mathrm{~g}$ of the polymer support which corresponded to $7.16 \%$ of Co intake. This further confirmed the formation of the complex on the polymer support. 


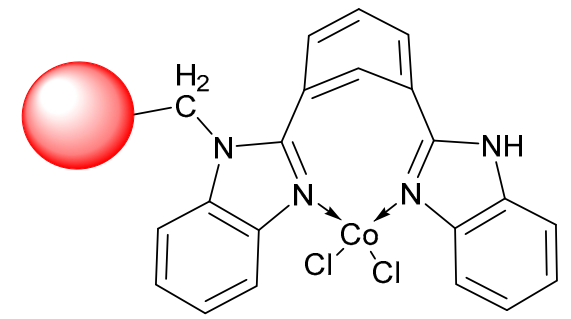

(A)

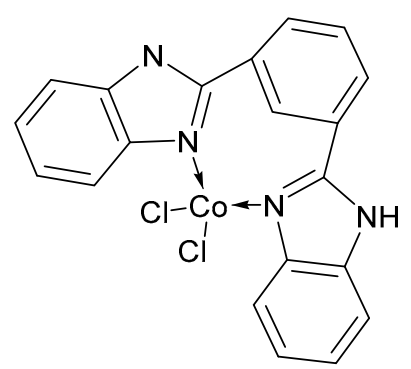

(B)

Figure 1. Structure of (A) PS-Co $(\mathrm{BBZN}) \mathrm{Cl}_{2}$ and (B) unbound $\mathrm{Co}(\mathrm{BBZN}) \mathrm{Cl}_{2}$.

Motivated by the increased understanding of the Co-catalyzed amination reaction, we next investigated the applicability of (PS-Co $\left(\mathrm{BBZN} \mathrm{Cl}_{2}\right)$ in the arylamination reaction. To examine this hypothesis, 1-(5-bromo-2-methoxyphenyl)adamantine (1a) and 4-chloro aniline (2a) were selected as model substrates and reagents for the reaction in 1,4-dioxane media and $\mathrm{Cs}_{2} \mathrm{CO}_{3}$ as a base (Scheme 2).

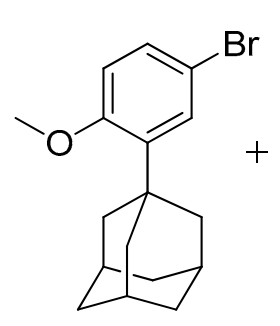

$1 \mathbf{a}$

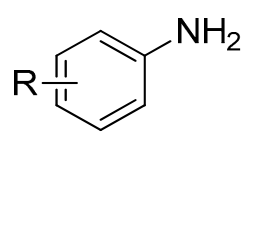

2a-I

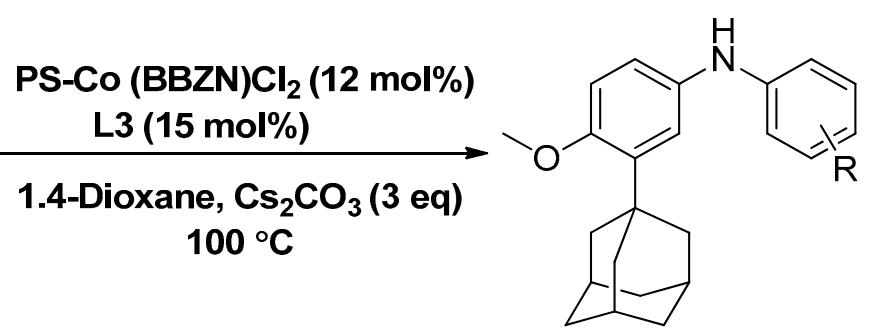

3a-I

Scheme 2. General scheme of arylamination reaction between adamantane bromide and various amines using $\mathrm{PS}-\mathrm{Co}(\mathrm{BBZN}) \mathrm{Cl}_{2}$ as a catalyst.

Control experiments established the importance of both PS-Co(BBZN) $\mathrm{Cl}_{2}$ and ligand, as no product was obtained (Table 1, entry 1). Gratifyingly, the substrate was transformed into the desired product 3-(adamantan-1-yl)-N-(4-chlorophenyl)-4-methoxyaniline (3a) with 51\% yield in the presence of catalyst (PS-Co(BBZN)Cl $\left.\mathrm{Cl}_{2}\right)(10 \mathrm{~mol} \%)$ and ligand $\mathbf{L 3}$ (Table 2, entry 10). Screening of various classes of ligands (Figure 2) to improve the yield revealed that the use of phosphine based ligand BINAP (L3) or Xphose (L4) gave improved yields at different catalyst concentrations (Table 1, entry 10, 11, 14, 15), whereas the other ligands such as bidentate ligands (L1, L2) and N-heterocyclic carbine ligands (L5, L6) yielded no products indicating the high role of selectivity of ligands in the forward reaction. The most robust reaction was achieved by the use of $12 \mathrm{~mol} \%$ of PS-Co(BBZN) $\mathrm{Cl}_{2}$ in the presence of BINAP with an $86 \%$ yield at $10 \mathrm{~h}$ reaction condition (Table 1, entry 14). Further investigation revealed that there was no considerable improvement in yield when the catalyst load was increased to $15 \mathrm{~mol} \%$ (Table 1 , entry 18, 19) whereas the yield dropped to $69 \%$ when the reaction time was reduced to $6 \mathrm{~h}$ with $15 \mathrm{~mol} \%$ catalyst (Table 1, entry 20). Using the above better protocol, we further synthesized ABTAs by reacting adamantine bromo compounds (1a) and various amines (Table 2). It was observed that all amine partners productively coupled with good yields of around $70-86 \%$.

All novel compounds exhibited spectral properties consistent with the assigned structures and were fully characterized by their spectroscopic data (mass, elemental, ${ }^{1} \mathrm{H}$ and ${ }^{13} \mathrm{C}$ NMR analysis).

The majority of reactions were done by keeping time point for $16 \mathrm{~h}$ and when the concentration of the catalyst was increased to $12 \%$, the reaction was completed in $12 \mathrm{~h}$ and in many cases pure product was produced with excellent yield. The above developed method tolerated the presence of substituent in the aromatic amino-compounds. Specifically, we observed that the electron-donating para-substituted aromatic amine partners were well-tolerated to produce corresponding products in 
good to excellent yields (Table 2, entries 1-12). However, ortho-substituted and electron-withdrawing group bearing compounds were not productive giving lower yields (Table 2, entries 5, 11, 12, 13).

Table 1. PS-Co(BBZN)Cl $\mathrm{Cl}_{2}$-catalyzed coupling of 1-(5-bromo-2-methoxyphenyl)adamantane with 4-Chloro aniline ${ }^{\mathrm{a}}$.

\begin{tabular}{ccccc}
\hline Entry & PS-Co(BBZN)Cl $_{\mathbf{2}}$ & Ligand $^{\mathbf{b}}$ & Time & Yield (\%) $^{\mathbf{c}}$ \\
\hline $\mathbf{1}$ & $5 \mathrm{~mol} \%$ & - & 16 & NR \\
$\mathbf{2}$ & $5 \mathrm{~mol} \%$ & $\mathrm{~L} 1$ & 16 & $\mathrm{NR}$ \\
$\mathbf{3}$ & $5 \mathrm{~mol} \%$ & $\mathrm{~L} 2$ & 16 & $\mathrm{NR}$ \\
$\mathbf{4}$ & $5 \mathrm{~mol} \%$ & $\mathrm{~L} 3$ & 16 & $\mathrm{NR}$ \\
$\mathbf{5}$ & $5 \mathrm{~mol} \%$ & $\mathrm{~L} 4$ & 16 & $\mathrm{NR}$ \\
$\mathbf{6}$ & $5 \mathrm{~mol} \%$ & $\mathrm{~L} 5$ & 16 & $\mathrm{NR}$ \\
$\mathbf{7}$ & $5 \mathrm{~mol} \%$ & $\mathrm{~L} 6$ & 16 & $\mathrm{NR}$ \\
$\mathbf{8}$ & $10 \mathrm{~mol} \%$ & $\mathrm{~L} 1$ & 16 & $\mathrm{NR}$ \\
$\mathbf{9}$ & $10 \mathrm{~mol} \%$ & $\mathrm{~L} 2$ & 16 & $\mathrm{NR}$ \\
$\mathbf{1 0}$ & $10 \mathrm{~mol} \%$ & $\mathrm{~L} 3$ & 16 & 51 \\
$\mathbf{1 1}$ & $10 \mathrm{~mol} \%$ & $\mathrm{~L} 4$ & 16 & 42 \\
$\mathbf{1 2}$ & $10 \mathrm{~mol} \%$ & $\mathrm{~L} 5$ & 16 & 20 \\
$\mathbf{1 3}$ & $10 \mathrm{~mol} \%$ & $\mathrm{~L} 6$ & 16 & 26 \\
$\mathbf{1 4}$ & $12 \mathrm{~mol} \%$ & $\mathrm{~L} 3$ & 10 & 86 \\
$\mathbf{1 5}$ & $12 \mathrm{~mol} \%$ & $\mathrm{~L} 4$ & 12 & 78 \\
$\mathbf{1 6}$ & $12 \mathrm{~mol} \%$ & $\mathrm{~L} 5$ & 16 & 36 \\
$\mathbf{1 7}$ & $12 \mathrm{~mol} \%$ & $\mathrm{~L} 6$ & 16 & 41 \\
$\mathbf{1 8}$ & $15 \mathrm{~mol} \%$ & $\mathrm{~L} 3$ & 10 & 86 \\
$\mathbf{1 9}$ & $15 \mathrm{~mol} \%$ & $\mathrm{~L} 4$ & 12 & 79 \\
$\mathbf{2 0}$ & $15 \mathrm{~mol} \%$ & $\mathrm{~L} 3$ & 6 & 69 \\
\hline
\end{tabular}

a Conditions: admantane-bromo compounds (1 mmol), 4-chloro aniline (1 mmol) (PS-Co (BBZN)Cl $)(12 \mathrm{~mol} \%) ; \mathrm{Cs}_{2} \mathrm{CO}_{3}$ (3 eq); 1,4 dioxane $(10 \mathrm{~mL}) ; \mathrm{N}_{2}$ atmosphere: $100^{\circ} \mathrm{C} .{ }^{\mathrm{b}}$ ligands $(15 \mathrm{~mol} \%)$ : $\mathrm{L} 1=2,2^{\prime}$-bipyridine, $\mathrm{L} 2=1,10$-phenanthroline; L3 = 2,2'-bis(diphenylphosphino)-1,1'-binaphthalene, L4 = dicyclohexyl(2-(2,4,6-trisopropylphenyl)cycohexyl)phosphine, L5 = 2,6-bis(3-methylimidazoline-1yl)pyridine, L6 = 1,3-dimessityl-4,5-dihydro-1H-imidazole-3-ium chloride; ${ }^{\mathrm{c}}$ isolated yield; $\mathrm{NR}=$ no reaction.

Table 2. PS-Co(BBZN) $\mathrm{Cl}_{2}$ composite-catalyzed coupling of various substituted halo aromatic compounds with various substituted aromatic amines ${ }^{\mathrm{a}}$.

Entry Amine


Catalysts 2020, 10, 1315

5 of 15

Table 2. Cont.
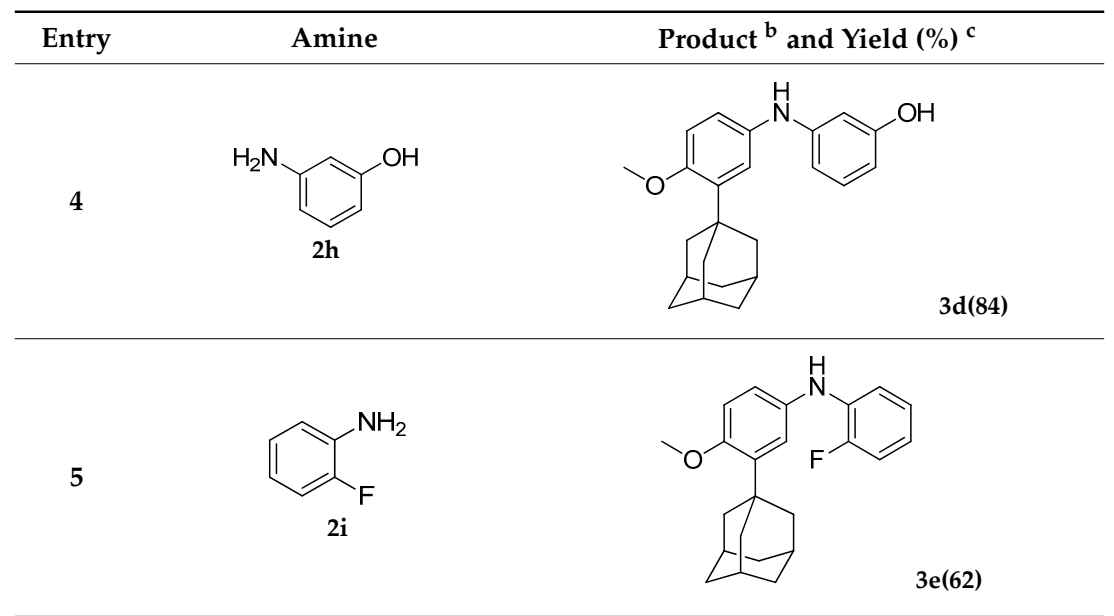

6<smiles>Cc1ccc(N)cc1</smiles>

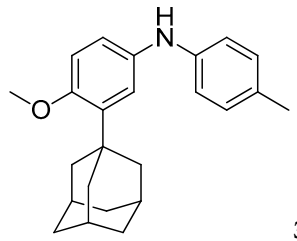

$3 f(87)$

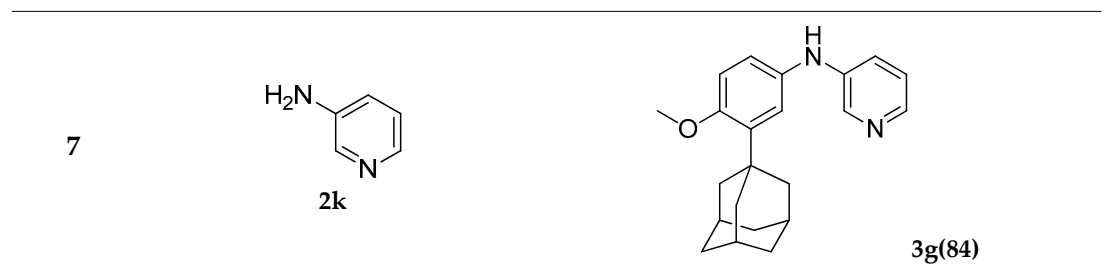

8

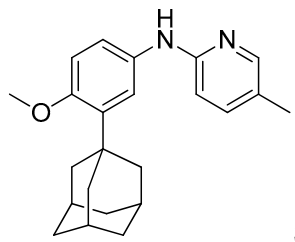

$3 h(80)$

9
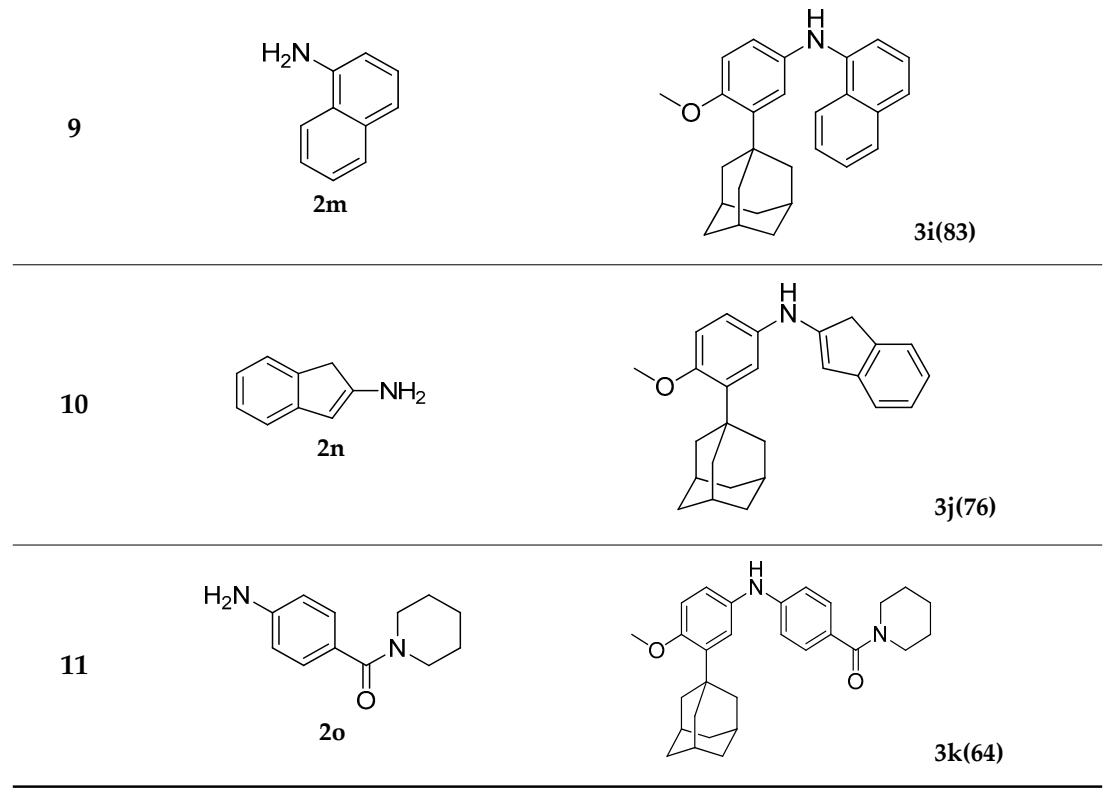
Table 2. Cont.

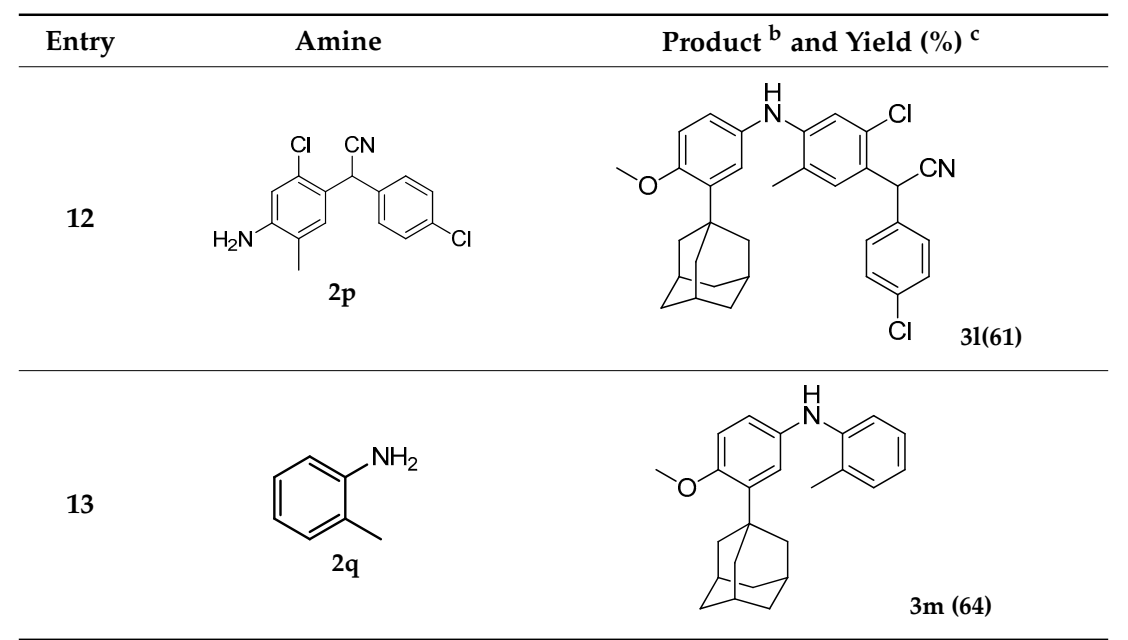

a Reaction conditions-Aromatic halo compounds $(1 \mathrm{mmol})$, aromatic amine $(1 \mathrm{mmol}), \mathrm{BINAP}(15 \mathrm{~mol} \%)$, PS-Co(BBZN)Cl $\mathrm{Cl}_{2}(12 \mathrm{~mol} \%), \mathrm{CS}_{2} \mathrm{CO}_{3}(3 \mathrm{mmol}), 1,4$-dioxane $(5 \mathrm{~mL}), \mathrm{N}_{2}$ atmosphere $10 \mathrm{~h}, 100{ }^{\circ} \mathrm{C}$. ${ }^{\mathrm{b}}$ All new compounds were characterized by their spectroscopic data shown in supporting information; ${ }^{c}$ isolated yield.

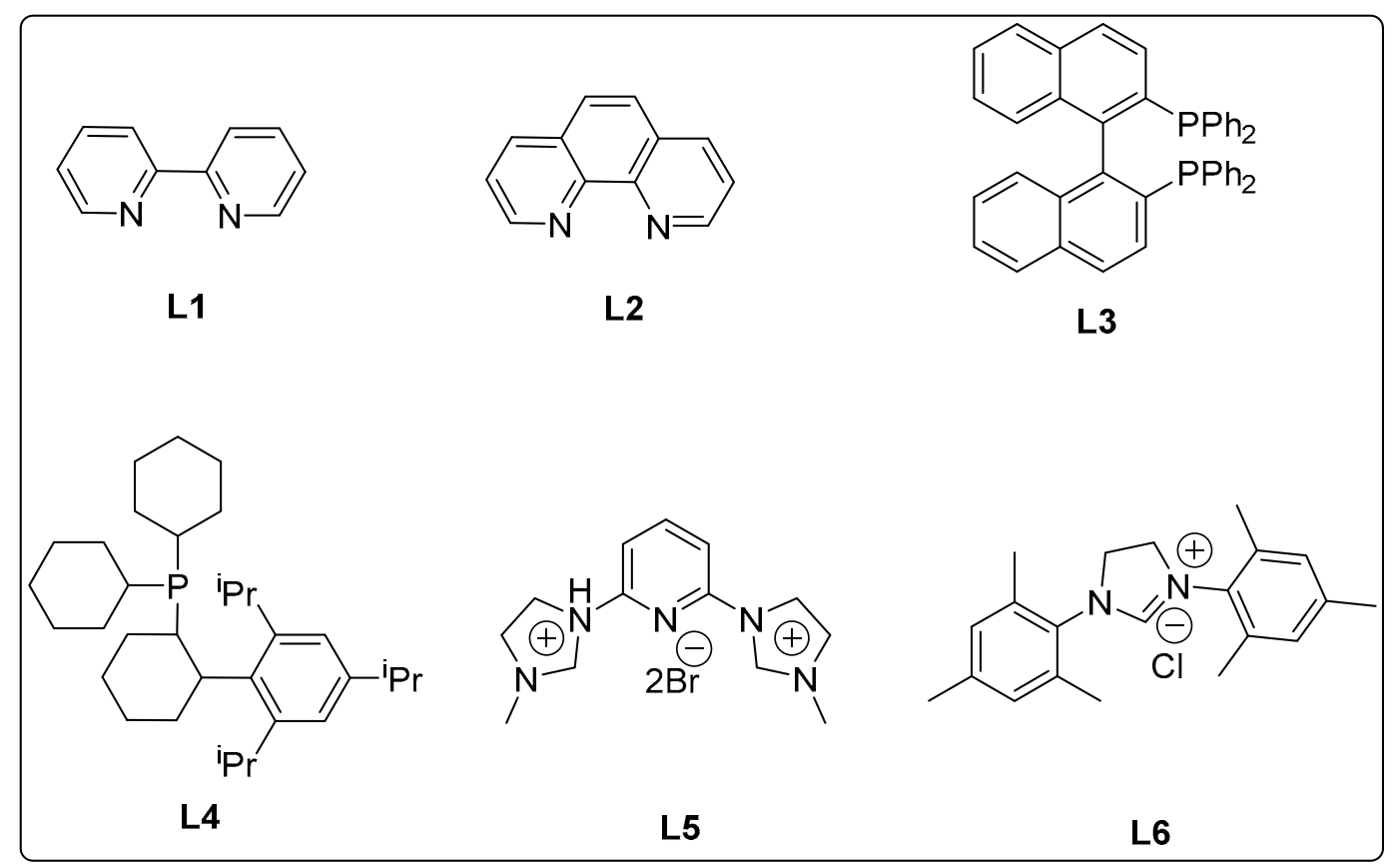

Figure 2. Various classes of ligands used in this study.

With the reaction conditions established we tried to investigate the scope of the new protocol on different substituted aromatic bromo compounds by treating with various amines (Table 3). We found that electron donating para-substituted on aromatic halo partner was tolerated well to give corresponding products in good to excellent yields (entries 1, 2, 3 and 5), but with ortho-substituted and electron-withdrawing group bearing aromatic bromo compounds observed a loss in yield (entries 4,6 and 7) with no improvement in the reaction conversion on prolonged reaction. 
Table 3. Various substrates and reagents used to optimization of arylamination reaction.

Entry

(2)

a Reported compounds.

All novel compounds exhibited spectral properties consistent with the assigned structures and were fully characterized by their spectroscopic data (mass, elemental, ${ }^{1} \mathrm{H}$ and ${ }^{13} \mathrm{C}$ NMR analysis). It was found that the use of a catalyst PS-Co(BBZN) $\mathrm{Cl}_{2}$, in combination with some ligands provided a robust catalytic system. On the basis of previous mechanistic studies in cobalt-catalyzed $\mathrm{C}-\mathrm{N}$ bond formation reactions, it was possible to propose a mechanism for the conversion of 3-(adamantan-1-yl)-N-(4-chlorophenyl)-4-methoxyaniline (3 a) as shown in Figure 3 [32-34]. 


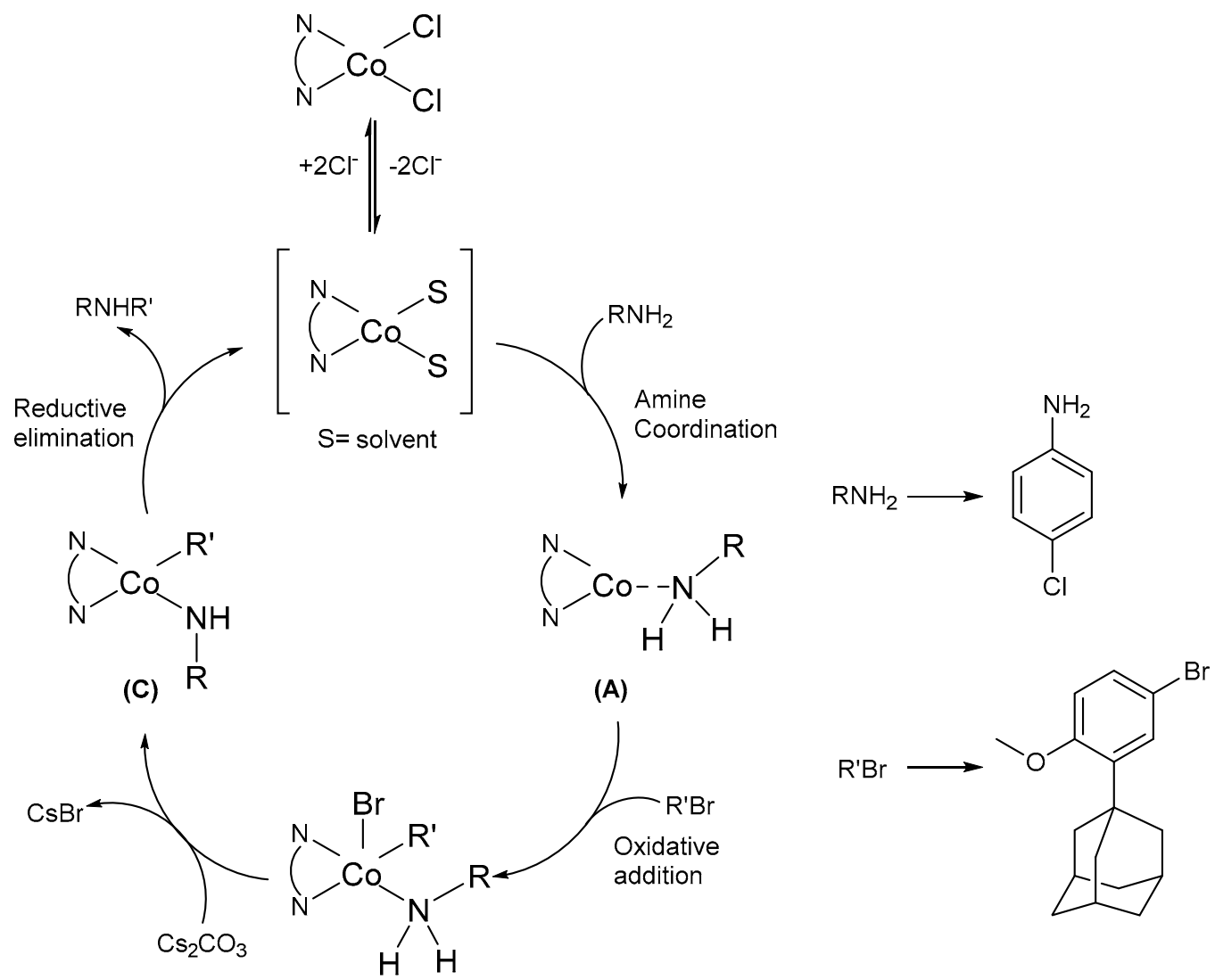

(B)

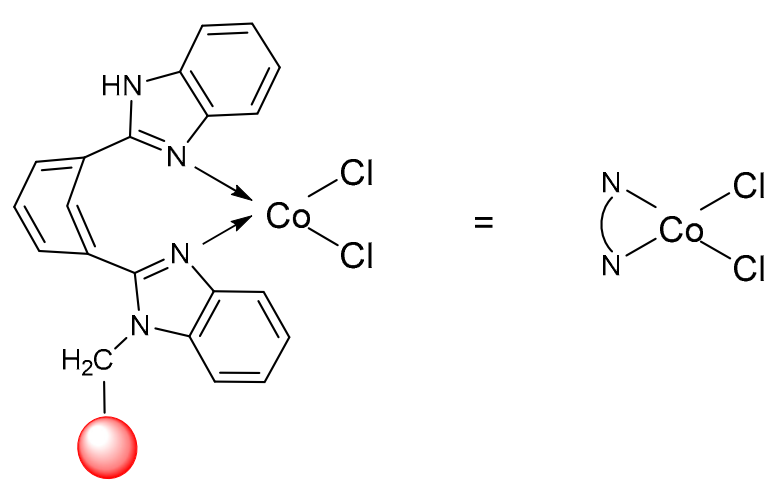

Figure 3. Plausible mechanism for the generation of arylamines using $\mathrm{PS}-\mathrm{Co}(\mathrm{BBZN}) \mathrm{Cl}_{2}$ as a catalyst.

Initially, the catalyst makes a complex with amine to form a catalyst-amine complex $\mathbf{A}$, which undergoes an oxidative addition reaction with 1-(5-bromo-2-methoxyphenyl)adamantane and complex $\mathbf{B}$ formation occurs. Complex $\mathbf{B}$ reacts with cesium carbonate base and undergoes metathesis step, which gave complex $\mathbf{C}$. Finally, the reductive elimination reaction complex $\mathbf{C}$ takes place and thereby catalyst regeneration and the desired product formation occur in the last step (Figure 3).

Further, we performed density-functional theory calculations using dispersion corrected CAM-B3 LYP functional and 6-31+G method [35]. All electron basis set as implemented in the Gaussian 09 package [36]. The minima nature of the structures has been confirmed based on computed real harmonic vibrational analysis at the same level of theory. Gibbs free energy calculations for four intermediate cobalt complexes were chosen for our mechanistic elucidation. Initially $\mathrm{CoCl}_{2}$ makes the coordination complex with the ligand and reacts with aromatic amine and forms $\mathrm{Co}-\mathrm{NH}$ bond quickly 
[intermediate (a); $\Delta \mathrm{E}=-6.03 \mathrm{kcal} / \mathrm{mole}$ ], which in turn gets stabilized by releasing $\mathrm{HCl}$ and attains a lower energy intermediate with a $\Delta \mathrm{E}$ of $-9.62 \mathrm{kcal} / \mathrm{mole}$. Alkyl bromide adds to the intermediate (b) quickly and attains still lower energy of $\Delta \mathrm{E}$ of $-17.18 \mathrm{kcal} / \mathrm{mole}$ where the bindentate ligand detachment takes place and immediate loss of $\mathrm{HCl}$ takes place and again attains lowest energy intermediate (d) of $\Delta \mathrm{E}=-19.62 \mathrm{kcal} / \mathrm{mole}$, which gives the product immediately. The optimized geometries and the energy profile diagram of intermediates (a-d) are shown in Figures 4 and 5, respectively. On the basis of lower Gibbs free energy of intermediates across (a) to (d), we can conclude that the reaction occurs naturally upon cobalt chloride coordination complex formation occurring with the bidentate ligands.
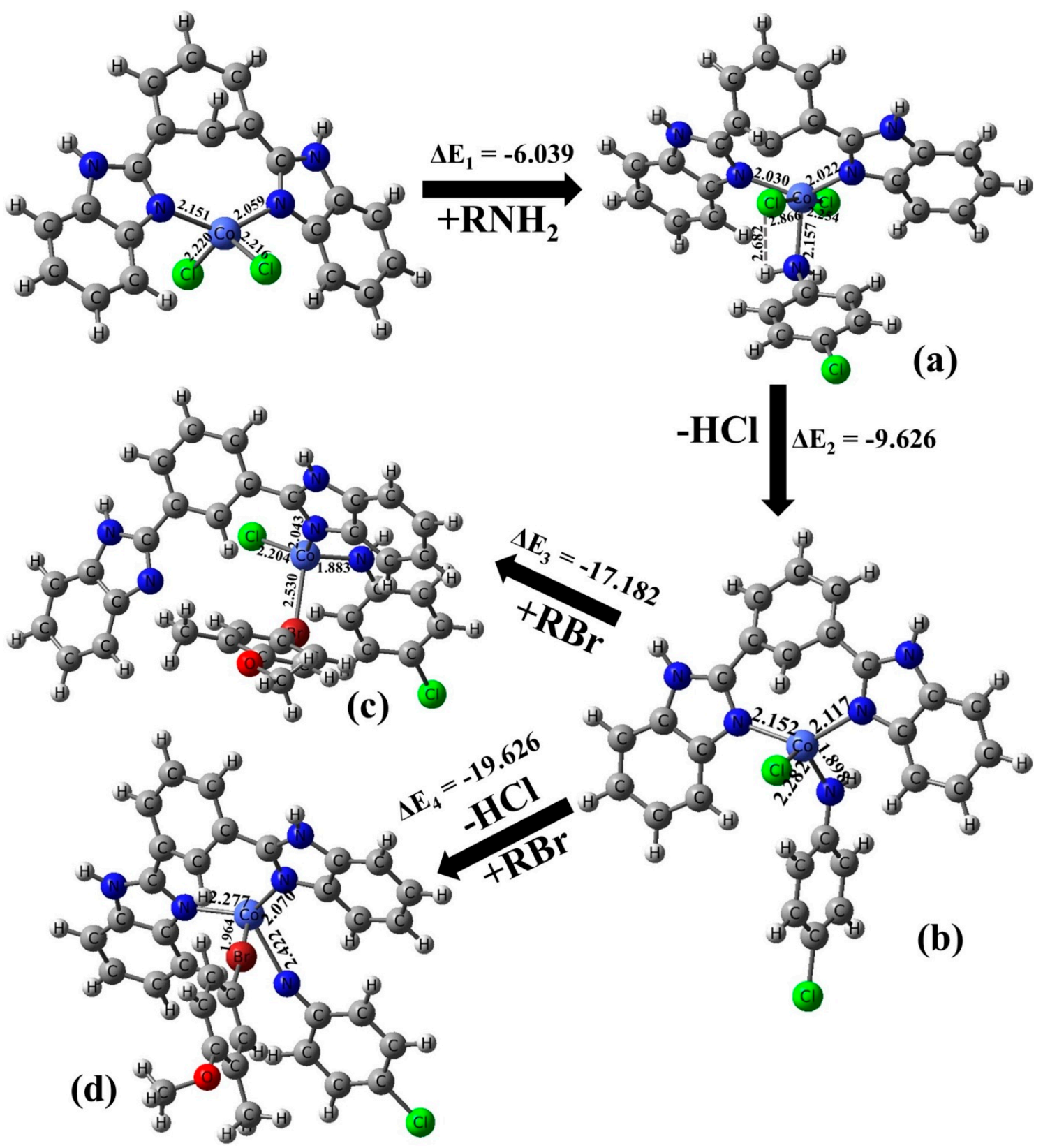


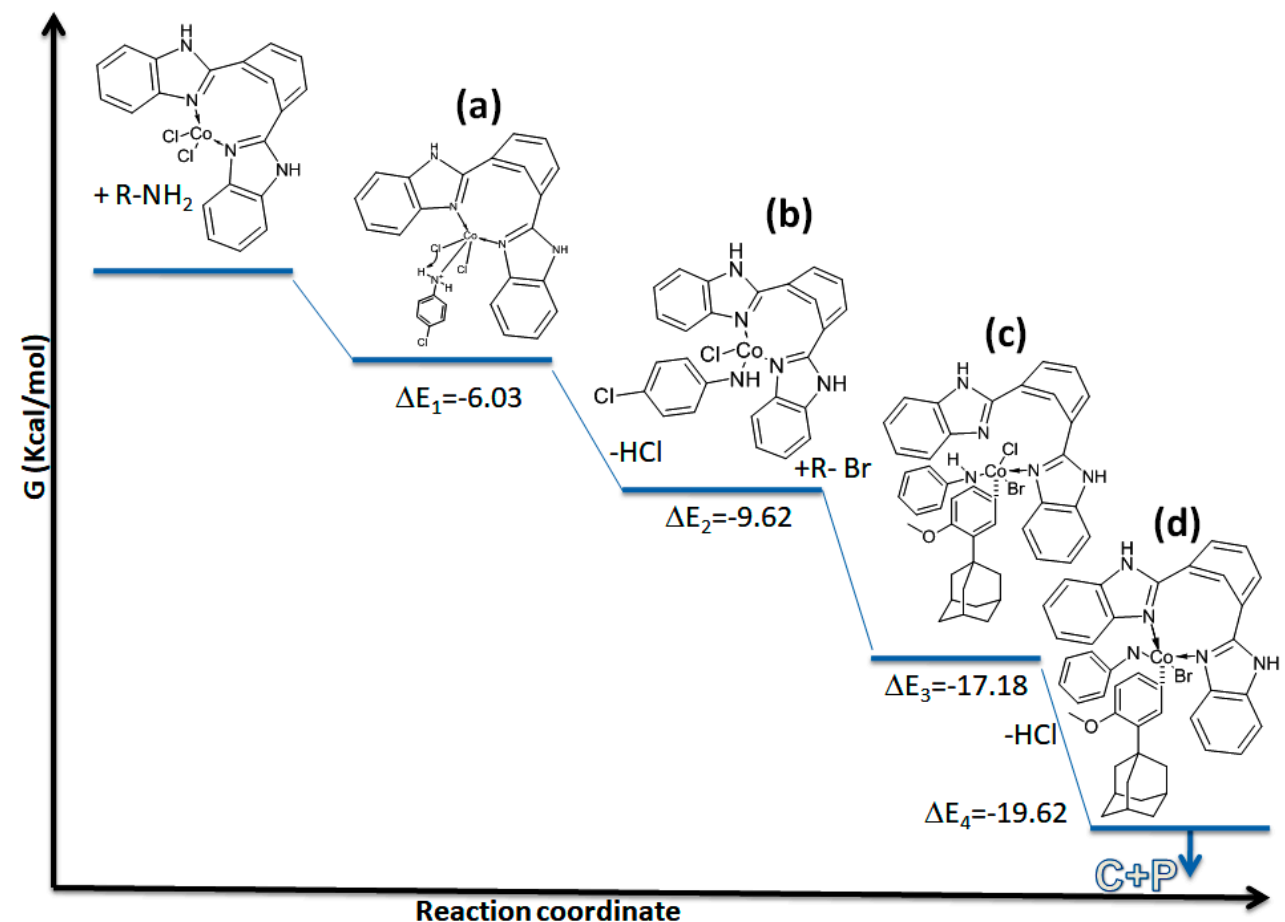

Figure 5. Energy profile diagram or arylamination reaction. $\mathrm{C}=$ catalyst; $\mathrm{P}=$ product.

\subsection{Recyclability of the Catalyst}

Further, the superiority of PS-Co(BBZN) $\mathrm{Cl}_{2}$ catalyst was its recyclability, which was investigated by using the compound $\mathbf{1} \mathbf{a}$ and $\mathbf{2} \mathbf{b}$ as a model reaction. After each run, the catalyst was filtered off and washed with water followed by methanol, it was then dried in an oven at $120^{\circ} \mathrm{C}$ for $15 \mathrm{~min}$ and used directly for the next reaction. The results were summarized (Table 4). We recorded that the catalyst could be used thrice and isolated yields achieved were above $70 \%$.

Table 4. The recycling of the catalyst ${ }^{\mathrm{a}}$.

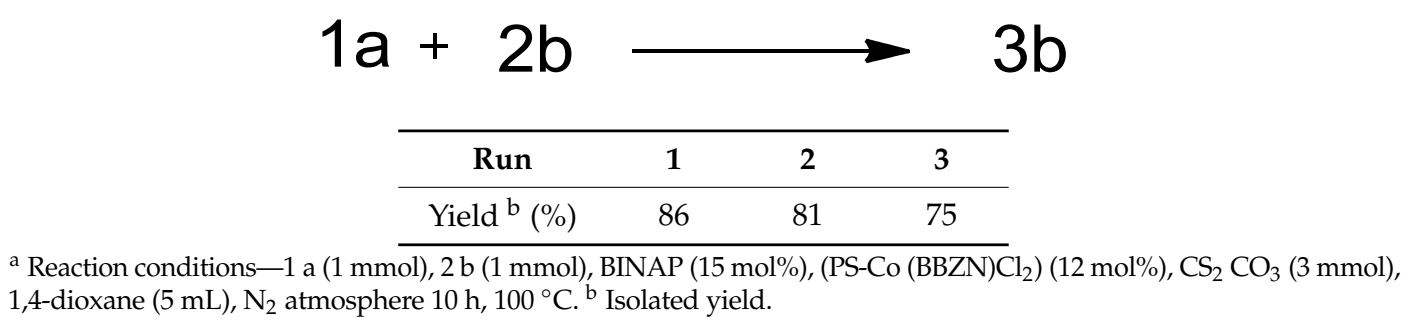

\section{Materials and Methods}

\subsection{Procedure for the Synthesis of PS-Co(BBZN)Cl $\mathrm{Cl}_{2}$ Complex}

\subsubsection{Preparation of BBZN Functionalized Polymer Support}

The chloromethylated polystyrene beads cross-linked with $6.5 \%$ divinylbenzene were first washed with a mixture of THF and water in the ratio 4:1 using Soxhlet extractor for $48 \mathrm{~h}$. The beads were then vacuum dried. The chloromethylated polystyrene beads $(3 \mathrm{~g})$ were allowed to swell in DMF solution of BBZN ligand ( $5.2 \mathrm{~g}$ ) was added to the above suspension followed by the addition of triethylamine $(12 \mathrm{~mL})$ in ethylacetate $(105 \mathrm{~mL})$ and was heated at $60^{\circ} \mathrm{C}$ for $45 \mathrm{~h}$ in a water bath. It was cooled to room temperature, filtered, and washed with DMF. The beads were then Soxhlet extracted with ethanol to remove any unreacted BBZN and dried in an oven at $60^{\circ} \mathrm{C}$ overnight. 


\subsubsection{Preparation of PS-Co(BBZN) $\mathrm{Cl}_{2}$ Complex}

The functionalized beads $(1.0 \mathrm{~g})$ were allowed to swell in $50 \mathrm{~mL}$ acetonitrile and toluene mixture in the ratio $1: 1 \mathrm{for} 1 \mathrm{~h}$. Then the solvent was decanted. To this, $1.426 \mathrm{~g}$ of $\mathrm{CoCl}_{2} \cdot 6 \mathrm{H}_{2} \mathrm{O}$ dissolved in methanol $(100 \mathrm{~mL})$ was added at intervals $\left(4\right.$ times) and heated at $60^{\circ} \mathrm{C}$ for $48 \mathrm{~h}$. It was filtered, washed with alcohol and Soxhlet extracted to remove any unreacted $\mathrm{CoCl}_{2} \cdot 6 \mathrm{H}_{2} \mathrm{O}$. It was filtered and dried in an oven at $60^{\circ} \mathrm{C}$ for $10 \mathrm{~h}$ and vacuum dried.

\subsection{General Procedure for (PS-Co(BBZN)Cl $l_{2}$ Complex Catalyzed C-N Bond-Formation Reaction}

A dried Schlenk tube was charged with substrate 1 a (320 mg, $1 \mathrm{mmol}), 2$ a $(127.6 \mathrm{mg}, 1 \mathrm{mmol})$, BINAP ( $48 \mathrm{mg}, 15 \mathrm{~mol} \%$ ), (PS-Co(BBZN)Cl $\mathrm{Cl}_{2}$ ] $\left(38 \mathrm{mg}, 12 \mathrm{~mol} \%\right.$ ). The tube was evacuated and backfilled with $\mathrm{N}_{2}$, and $\mathrm{Cs}_{2} \mathrm{CO}_{3}(975 \mathrm{mg}, 3 \mathrm{mmol})$ followed by reagent grade 1, 4-dioxane $(5 \mathrm{~mL})$. The reaction mixture was heated to $100^{\circ} \mathrm{C}$ for $10 \mathrm{~h}$. After completion of reaction the mass was cooled to room temperature, filtered off the catalyst, the solvent quenched with water and diluted with ethyl acetate $(10 \mathrm{~mL})$. The layers were separated, and the aqueous layer was extracted with $(5 \mathrm{~mL})$ ethyl acetate. The combined organic layer was washed with water $(10 \mathrm{~mL})$, dried over anhydrous sodium sulphate and the solvent was removed in vacuum. The crude product was purified using silica gel column chromatography.

\subsubsection{3-(Adamantan-1-yl)-N-(4-chlorophenyl)-4-methoxyaniline (3 a)}

Pale Yellow colored solid; mp 140-142 ${ }^{\circ} \mathrm{C}:{ }^{1} \mathrm{H}$ NMR $\left(400 \mathrm{MHz}, \mathrm{CDCl}_{3}\right) 7.14-7.12(\mathrm{~d}, \mathrm{~J}=8.0 \mathrm{~Hz}$, $2 \mathrm{H}), 6.95-6.91(\mathrm{~m}, 2 \mathrm{H}), 6.81-6.78(\mathrm{~m}, 3 \mathrm{H}), 5.46(\mathrm{~s}, 1 \mathrm{H}), 3.80(\mathrm{~s}, 3 \mathrm{H}), 2.05(\mathrm{~m}, 9 \mathrm{H}), 1.74(\mathrm{~m}, 6 \mathrm{H})$; ${ }^{13} \mathrm{C}$ NMR (100 MHz,CDCl3) 155.0, 144.2, 139.9, 134.8, 129.2, 123.6, 120.6, 119.1, 116.4, 112.6, 55.4, 40.6, 37.1, 29.1; LCMS (MM : ES + APCI) 368.4 (M + H) ${ }^{+}$; Anal.Calcd for $\mathrm{C}_{23} \mathrm{H}_{26}$ CINO: C, 75.08; H, 7.12; N, 3.81. Found: $\mathrm{C}, 75.01 ; \mathrm{H}, 7.15 ; \mathrm{N}, 3.88$.

\subsubsection{3-(Adamantan-1-yl)-4-methoxy-N-(4-methoxyphenyl)aniline (3 b)}

Brown colored solid; mp 117-119 ${ }^{\circ} \mathrm{C}:{ }^{1} \mathrm{H}$ NMR $\left(400 \mathrm{MHz}, \mathrm{CDCl}_{3}\right) 7.48-7.46(\mathrm{~d}, \mathrm{~J}=8.0 \mathrm{~Hz}, 2 \mathrm{H})$, $7.24(\mathrm{~m}, 1 \mathrm{H}), 6.88-6.86(\mathrm{~d}, \mathrm{~J}=8.0 \mathrm{~Hz}, 2 \mathrm{H}), 6.72-6.70(\mathrm{~d}, \mathrm{~J}=8.0 \mathrm{~Hz}, 2 \mathrm{H}), 5.39(\mathrm{~s}, 1 \mathrm{H}), 3.89(\mathrm{~s}, 3 \mathrm{H})$, $3.83(\mathrm{~s}, 3 \mathrm{H}), 2.06-2.03(\mathrm{~m}, 9 \mathrm{H}), 1.75(\mathrm{~m}, 6 \mathrm{H}) ;{ }^{13} \mathrm{C} \mathrm{NMR}\left(100 \mathrm{MHz}, \mathrm{CDCl}_{3}\right)$ 153.8, 142.2, 138.9, 130.4, 128.2, 122.5, 118.1, 115.5, 111.8, 55.0, 53.7, 40.3, 36.96, 28.9; LCMS (MM : ES + APCI) $364.4(\mathrm{M}+\mathrm{H})^{+}$; Anal.Calcd for $\mathrm{C}_{24} \mathrm{H}_{29} \mathrm{NO}_{2}$ : C, 79.30; $\mathrm{H}, 8.04 ; \mathrm{N}, 3.85$. Found: $\mathrm{C}, 79.26 ; \mathrm{H}, 8.11 ; \mathrm{N}, 3.79$.

\subsubsection{3-(Adamantan-1-yl)-4-methoxy-N-(4-(trifluoromethyl)phenyl)aniline (3 c)}

Off-white colored solid; mp 124-126 ${ }^{\circ} \mathrm{C}:{ }^{1} \mathrm{H}$ NMR $\left(400 \mathrm{MHz}, \mathrm{CDCl}_{3}\right) 7.64-7.61(\mathrm{~m}, 2 \mathrm{H}), 7.45-7.39$ $(\mathrm{m}, 3 \mathrm{H}), 7.24(\mathrm{~s}, 1 \mathrm{H}), 6.96-6.94(\mathrm{~d}, \mathrm{~J}=8.0 \mathrm{~Hz}, 1 \mathrm{H}), 5.36(\mathrm{~s}, 1 \mathrm{H}), 3.87(\mathrm{~s}, 3 \mathrm{H}), 2.13-2.04(\mathrm{~m}, 9 \mathrm{H}), 1.77$ $(\mathrm{m}, 6 \mathrm{H}) ;{ }^{13} \mathrm{C}$ NMR $\left(100 \mathrm{MHz}, \mathrm{CDCl}_{3}\right)$ 159.1, 145.1, 139.1, 131.8, 127.0, $125.7(\mathrm{JCF}=25.7 \mathrm{~Hz}), 112.1,55.2$, 40.6, 37.2 (JCF $=7.6 \mathrm{~Hz}), 29.7,29.1$; LCMS (MM : ES + APCI) $402.2(\mathrm{M}+\mathrm{H})^{+}$; Anal.Calcd for $\mathrm{C}_{24} \mathrm{H}_{26} \mathrm{~F}_{3}$ NO: C, 71.80; H, 6.53; N, 3.49. Found: C, 71.76; H, 6.59; N, 3.41.

\subsubsection{3-((3-(Adamantan-1-yl)-4-methoxyphenyl)amino)phenol (3 d)}

Off-white colored solid; mp 98-100 ${ }^{\circ} \mathrm{C} ;{ }^{1} \mathrm{H}$ NMR $(400 \mathrm{MHz}, \mathrm{CDCl} 3) 7.43$ (s, $\left.1 \mathrm{H}\right), 7.08$ (s, $\left.1 \mathrm{H}\right)$, 6.99-6.96 (m, $4 \mathrm{H}), 6.84-6.82(\mathrm{~d}, \mathrm{~J}=8.0 \mathrm{~Hz}, 1 \mathrm{H}), 5.62(\mathrm{~s}, 1 \mathrm{H}), 4.80(\mathrm{~s}, 1 \mathrm{H}), 3.82(\mathrm{~s}, 3 \mathrm{H}), 2.05(\mathrm{~m}, 9 \mathrm{H})$, $1.74(\mathrm{~m}, 6 \mathrm{H}) ;{ }^{13} \mathrm{C}$ NMR $(100 \mathrm{MHz}, \mathrm{CDCl} 3)$ 159.2, 154.3, 146.2, 139.9, 129.7, 121.3, 119.9, 117.7, 115.3, 112.6, 111.2, 55.4, 40.6, 37.1, 29.1; HRMS Calcd 372.1934 Found: $372.1938(\mathrm{M}+\mathrm{H})^{+}$; Anal.Calcd for $\mathrm{C}_{24}$ $\mathrm{H}_{29} \mathrm{NO}_{2}: \mathrm{C}, 79.30 ; \mathrm{H}, 8.04 ; \mathrm{N}, 3.85$. Found: $\mathrm{C}, 79.26 ; \mathrm{H}, 8.11 ; \mathrm{N}, 3.79$.

\subsubsection{3-(Adamantan-1-yl)-N-(2-fluorophenyl)-4-methoxyaniline (3 e)}

Yellow colored solid; mp 106-108 ${ }^{\circ} \mathrm{C}:{ }^{1} \mathrm{H}$ NMR $\left(400 \mathrm{MHz}, \mathrm{CDCl}_{3}\right) 7.10-7.06(\mathrm{~m}, 1 \mathrm{H}), 6.98-6.96$ $(\mathrm{dd}, \mathrm{J} 1=2.7 \mathrm{~Hz}, \mathrm{~J} 2=2.2 \mathrm{~Hz}, 2 \mathrm{H}), 6.84-6.83(\mathrm{~d}, \mathrm{~J}=4.0 \mathrm{~Hz}, 1 \mathrm{H}), 6.81(\mathrm{~s}, 1 \mathrm{H}), 5.50(\mathrm{~s}, 1 \mathrm{H}), 3.81(\mathrm{~s}, 3 \mathrm{H})$, 2.05 (m, $9 \mathrm{H}), 1.75(\mathrm{~m}, 6 \mathrm{H}) ;{ }^{13} \mathrm{C} \mathrm{NMR}\left(100 \mathrm{MHz} \mathrm{CDCl}_{3}\right)$ 158.4, 155.4, 147.1, 139.9, 134.1, 130.3, 121.5, 
120.0, 118.8, 114.6, $112.8(\mathrm{JCF}=53.4 \mathrm{~Hz}), 55.4,40.5,37.2,29.0$; LCMS $(\mathrm{MM}: \mathrm{ES}+\mathrm{APCI}) 352.4(\mathrm{M}+\mathrm{H})^{+}$; Anal.Calcd for $\mathrm{C}_{23} \mathrm{H}_{26}$ FNO: C, 78.60; H, 7.46; N, 3.99. Found: C, 78.71; H, 7.39; N, 3.91.

3.2.6. 3-(Adamantan-1-yl)-4-methoxy-N-(p-tolyl)aniline (3 f )

Off-white colored solid; mp 108-110 ${ }^{\circ} \mathrm{C}:{ }^{1} \mathrm{H}$ NMR $\left(400 \mathrm{MHz}, \mathrm{CDCl}_{3}\right) 7.03-7.01(\mathrm{~d}, \mathrm{~J}=8.0 \mathrm{~Hz}, 2 \mathrm{H})$, $6.95-6.89(\mathrm{dd}, \mathrm{J} 1=4.0 \mathrm{~Hz}, \mathrm{~J} 2=4.0 \mathrm{~Hz}, 2 \mathrm{H}), 6.85-6.83(\mathrm{~d}, \mathrm{~J}=8.0 \mathrm{~Hz}, 2 \mathrm{H}), 6.80-6.78(\mathrm{~d}, \mathrm{~J}=8.0 \mathrm{~Hz}, 1 \mathrm{H}), 5.39$ (s, $1 \mathrm{H}), 3.80$ (s, $3 \mathrm{H}), 2.26$ (s, $3 \mathrm{H}), 2.05(\mathrm{~m}, 9 \mathrm{H}), 1.74(\mathrm{~m}, 6 \mathrm{H}) ;{ }^{13} \mathrm{C} \mathrm{NMR}\left(100 \mathrm{MHz}, \mathrm{CDCl}_{3}\right)$ 154.2, 142.6, 139.7, 129.8, 128.9, 119.4, 117.6, 116.3, 112.7, 55.5, 40.6, 37.1, 37.0, 29.1, 20.6; LCMS (MM : ES + APCI) 348.4 $(\mathrm{M}+\mathrm{H})^{+}$; Anal. Calcd for $\mathrm{C}_{24} \mathrm{H}_{29}$ NO: $\mathrm{C}, 82.95 ; \mathrm{H}, 8.41 ; \mathrm{N}$, 4.03. Found: $\mathrm{C}, 82.90 ; \mathrm{H}, 8.46 ; \mathrm{N}, 3.99$.

3.2.7. N-(3-Adamantan-1-yl)-4-methoxyphenyl)pyridin-3-amine (3 g)

Pale yellow colored solid; mp 103-104 ${ }^{\circ} \mathrm{C} ;{ }^{1} \mathrm{H}$ NMR $\left(400 \mathrm{MHz}, \mathrm{CDCl}_{3}\right) 8.42-8.41(\mathrm{~d}, \mathrm{~J}=4.0 \mathrm{~Hz}$, $1 \mathrm{H}), 7.47-7.43(\mathrm{~m}, 2 \mathrm{H}), 7.29-7.27(\mathrm{~m}, 2 \mathrm{H}), 7.23-7.22(\mathrm{~m}, 2 \mathrm{H}), 5.58(\mathrm{~s}, 1 \mathrm{H}), 3.85(\mathrm{~s}, 3 \mathrm{H}), 2.14-207(\mathrm{~m}$, $9 \mathrm{H}), 1.79-1.73(\mathrm{~m}, 6 \mathrm{H}) ;{ }^{13} \mathrm{C} \mathrm{NMR}\left(100 \mathrm{MHz}, \mathrm{CDCl}_{3}\right)$ 161.9, 153.0, 143.7, 136.1, 126.8, 125.9, 124.0, 123.0, 121.9, 117.6, 115.1, 56.1, 40.8, 38.0, 28.6; LCMS (MM : ES + APCI) 335.4 (M + H) ${ }^{+}$; Anal. Calcd for $\mathrm{C}_{22}$ $\mathrm{H}_{26} \mathrm{~N}_{2} \mathrm{O}: \mathrm{C}, 79.00 ; \mathrm{H}, 7.84 ; \mathrm{N}$, 8.38. Found: C, 79.08; H, 7.79; N, 8.33.

3.2.8. N-(3-Adamantan-1-yl)-4-methoxyphenyl)-5-methylpyridin-2-amine (3 h)

Off-white colored solid; mp 101-102 ${ }^{\circ} \mathrm{C}:{ }^{1} \mathrm{H}$ NMR $\left(400 \mathrm{MHz}, \mathrm{CDCl}_{3}\right) ; 8.42(\mathrm{~s}, 1 \mathrm{H}), 7.53-7.47$ (m, $3 \mathrm{H}), 7.03-7.01(\mathrm{~d}, \mathrm{~J}=8.0 \mathrm{~Hz}, 2 \mathrm{H}), 5.60(\mathrm{~s}, 1 \mathrm{H}), 3.83(\mathrm{~s}, 3 \mathrm{H}), 2.30(\mathrm{~s}, 3 \mathrm{H}), 2.09(\mathrm{~m}, 9 \mathrm{H}), 1.78(\mathrm{~m}, 6 \mathrm{H})$; ${ }^{13} \mathrm{C}$ NMR (100 MHz, CDCl3) 160.2, 155.2, 145.0, 139.2, 128.9, 126.4, 121.4, 119.5, 117.4, 115.7, 54.8, 39.9, 36.4, 27.5, 27.0, 21.9; HRMS Calcd: 371.2094; Found: $371.2098(\mathrm{M}+\mathrm{H})^{+}$; Anal. Calcd for $\mathrm{C}_{23} \mathrm{H}_{28} \mathrm{~N}_{2} \mathrm{O}$ : C, 79.27; H, 8.10; N, 8.04. Found: C, 79.32; H, 7.99; N, 8.09.

\subsubsection{N-(3-Adamantan-1-yl)-4-methoxyphenyl)naphthalen-1-amine (3 i)}

Pale yellow colored solid; $\mathrm{mp} 105-106{ }^{\circ} \mathrm{C} ;{ }^{1} \mathrm{H}$ NMR $\left(400 \mathrm{MHz}, \mathrm{CDCl}_{3}\right) 8.09-8.07(\mathrm{~d}, \mathrm{~J}=8.0 \mathrm{~Hz}, 1 \mathrm{H})$, 8.03-8.01 (d, J = 8.0 Hz, $1 \mathrm{H}), 7.96-7.94(\mathrm{~d}, \mathrm{~J}=8 \mathrm{~Hz}, 1 \mathrm{H}), 7.60-7.28(\mathrm{~m}, 6 \mathrm{H}), 5.51(\mathrm{~s}, 1 \mathrm{H}), 3.83(\mathrm{~s}, 3 \mathrm{H})$, 2.13-2.05 (m, $9 \mathrm{H}), 1.76-1.73(\mathrm{~m}, 6 \mathrm{H}) ;{ }^{13} \mathrm{C}$ NMR $\left(100 \mathrm{MHz}, \mathrm{CDCl}_{3}\right)$ 153.9, 145.7, 138.3, 133.9, 132.7, 131.9, 128.7, 128.3, 128.2, 127.1, 126.9, 126.3, 125.9, 125.5, 111.4, 55.2, 40.4, 37.2, 29.2; LCMS (MM : ES + APCI) $384.4(\mathrm{M}+\mathrm{H})^{+}$; Anal.Calcd for $\mathrm{C}_{27} \mathrm{H}_{29} \mathrm{NO}$ C, $84.55 ; \mathrm{H}, 7.62 ; \mathrm{N}, 3.65$. Found: $\mathrm{C}, 84.61 ; \mathrm{H}, 7.59 ; \mathrm{N}, 3.69$.

3.2.10. N-(3-Adamantan-1-yl)-4-methoxyphenyl)-1 H-inden-2-amine (3 j)

Pale yellow colored solid; $\mathrm{mp} 116-118^{\circ} \mathrm{C}:{ }^{1} \mathrm{H}$ NMR $\left(400 \mathrm{MHz}, \mathrm{CDCl}_{3}\right) 7.64-7.61(\mathrm{~m}, 2 \mathrm{H}), 7.45-7.39$ (m, 3 H), 6.96-7.94 (d, J = 8 Hz, 2 H), 6.19 (s, 1 H), $5.34(\mathrm{~s}, 1 \mathrm{H}), 3.83(\mathrm{~s}, 3 \mathrm{H}), 3.29(\mathrm{~s}, 2 \mathrm{H}), 2.13-2.07$ (m, $9 \mathrm{H}), 1.77$ (m, $6 \mathrm{H}) ;{ }^{13} \mathrm{C} \mathrm{NMR}\left(100 \mathrm{MHz}, \mathrm{CDCl}_{3}\right)$ 154.0, 144.4, 138.9, 132.0, 130.0, 126.0, 125.9, 120.1, 119.9, 115.5, 104.4, 55.4, 44.3, 40.8, 37.3, 29.7, 29.2; LCMS (MM : ES + APCI) $372.2(\mathrm{M}+\mathrm{H})^{+}$Anal.Calcd for $\mathrm{C}_{27} \mathrm{H}_{29} \mathrm{NO}$ C, 84.06; H, 7.87; N, 3.77. Found: C, 84.11; H, 7.94; N, 3.72 .

\subsubsection{4.((3-(Adamantan-1-yl)-4-methoxyphenyl)amino)phenyl)(piperidin-1-yl)methanone (3 k)}

Off-white colored solid; mp 121-122 ${ }^{\circ} \mathrm{C} ;{ }^{1} \mathrm{H}$ NMR $\left(400 \mathrm{MHz}, \mathrm{CDCl}_{3}\right)$ 7.65-7.62 (m, $\left.2 \mathrm{H}\right), 7.45-7.39$ $(\mathrm{m}, 3 \mathrm{H}), 6.97-6.95(\mathrm{~d}, \mathrm{~J}=8.0 \mathrm{~Hz}, 1 \mathrm{H}), 5.37(\mathrm{~s}, 1 \mathrm{H}), 3.87(\mathrm{~s}, 3 \mathrm{H}), 3.47-3.39(\mathrm{~m}, 4 \mathrm{H}), 2.14-2.13(\mathrm{~m}, 9 \mathrm{H})$, 2.08-2.04 (m, $3 \mathrm{H}), 1.78(\mathrm{~m}, 6 \mathrm{H}), 1.45(\mathrm{~m}, 6 \mathrm{H}) ;{ }^{13} \mathrm{C} \mathrm{NMR}\left(100 \mathrm{MHz}, \mathrm{CDCl}_{3}\right)$ 170.4, 155.2, 145.6, 138.9, 131.8, 127.0, 125.8, 125.6, 112.5, 55.5, 46.2, 40.5, 37.2, 37.1, 29.7, 29.1, 24.4; LCMS (MM : ES + APCI) 445.2 $(\mathrm{M}+\mathrm{H})^{+}$; Anal.Calcd for $\mathrm{C}_{29} \mathrm{H}_{36} \mathrm{~N}_{2} \mathrm{O}_{2}$ : C 78.34; $\mathrm{H}$ 8.16; N 6.30; Found: C 78.39; H 8.10; $\mathrm{N}$ 6.24.

3.2.12. 2.(4-((3-Adamantan-1-yl)-4-methoxyphenyl)amino)-2-chloro-5-methylphenyl)-2-(4chlorophenyl)acetonitrile (3 1)

Yellow colored solid; $\mathrm{mp} 129-132{ }^{\circ} \mathrm{C} ;{ }^{1} \mathrm{H}$ NMR $\left(300 \mathrm{MHz}, \mathrm{CDCl}_{3}\right) 7.62-7.51(\mathrm{~m}, 3 \mathrm{H}), 7.32-7.26(\mathrm{~m}$, $2 \mathrm{H}), 6.84-6.81(\mathrm{~d}, \mathrm{~J}=12.0 \mathrm{~Hz}, 2 \mathrm{H}), 6.35-6.25(\mathrm{~m}, 2 \mathrm{H}), 5.66(\mathrm{~s}, 1 \mathrm{H}), 5.27(\mathrm{~s}, 1 \mathrm{H}), 3.82(\mathrm{~s}, 3 \mathrm{H}), 2.16-1.66$ 
(m, $18 \mathrm{H}) ;{ }^{13} \mathrm{C} \mathrm{NMR}\left(75 \mathrm{MHz}, \mathrm{CDCl}_{3}\right)$ 156.0, 1139.8, 136.6, 133.3, 126.8, 125.8, 125.6, 123.3, 121.7, 117.6, 55.3, 42.5, 41.6, 41.1, 40.9, 36.9, 36.5, 36.1, 35.6, 28.5, 27.9, 18.13; HRMS Calcd: 553.1784; Found: 553.1892 $(\mathrm{M}+\mathrm{H})^{+}$; Anal.Calcd for $\mathrm{C}_{32} \mathrm{H}_{32} \mathrm{Cl}_{2} \mathrm{~N}_{2} \mathrm{O}$ : C 72.31; H 6.07; N 5.27; Found: C 72.39; H 6.01; N 5.24.

Off-white colored solid; $\mathrm{mp} 118-120{ }^{\circ} \mathrm{C}$; 3-(adamantan-1-yl)-4-methoxy-N-(o-tolyl)aniline (3 m): ${ }^{1} \mathrm{H}$ NMR $(400 \mathrm{MHz}, \mathrm{CDCl} 3) 7.40(\mathrm{~s}, 1 \mathrm{H}), 7.36(\mathrm{~d}, 1 \mathrm{H}), 7.17-7.10(\mathrm{~m}, 4 \mathrm{H}), 6.94(\mathrm{~d}, 1 \mathrm{H}), 5.37(\mathrm{~s}, 1 \mathrm{H})$, $3.87(\mathrm{~s}, 3 \mathrm{H}), 2.41(\mathrm{~s}, 3 \mathrm{H}), 2.14(\mathrm{~m}, 6 \mathrm{H}), 2.06(\mathrm{~m}, 3 \mathrm{H}), 1.77(\mathrm{~m}, 6 \mathrm{H})$; HRMS Calcd 370.214. Found: $370.212(\mathrm{M}+\mathrm{H})^{+}$.

6-Chloro-N-(p-tolyl)-9 H-fluoren-2-amine (5 b)

Yellow colored solid; mp 131-132 ${ }^{\circ} \mathrm{C}^{1} \mathrm{H}$ NMR (400 MHz, DMSO-d $\left.)_{6}\right) ; 8.10(\mathrm{~s}, 1 \mathrm{H}), 8.05-8.03(\mathrm{~d}$, $\mathrm{J}=8 \mathrm{~Hz}, 1 \mathrm{H}), 7.76(\mathrm{~s}, 1 \mathrm{H}), 7.53-7.51(\mathrm{~d}, \mathrm{~J}=8.0 \mathrm{~Hz}, 1 \mathrm{H}), 7.38-7.21(\mathrm{~m}, 4 \mathrm{H}), 7.16-7.12(\mathrm{~m}, 2 \mathrm{H}), 5.36(\mathrm{~s}$, $1 \mathrm{H}), 4,37$ (s, $2 \mathrm{H}), 2.39$ (s, $3 \mathrm{H}) ;{ }^{13} \mathrm{C}$ NMR (100 MHz, DMSO-d 6 ); 140.7, 140.5, 137.8, 135.5, 129.1, 127.8, 127.5, 127.0, 125.4, 123.2, 121.4, 119.9, 112.1, 110.6, 41.20, 23.5; HRMS Calcd 328.0863; Found: 328.0866 $(\mathrm{M}+\mathrm{Na})^{+}$; Anal.Calcd for $\mathrm{C}_{20} \mathrm{H}_{16} \mathrm{ClN}$ : C, 78.55; H, 5.27; N, 4.58; Found: $\mathrm{C}, 78.58 ; \mathrm{H}, 5.21 ; \mathrm{N}, 4.55$.

$\mathrm{N}$-(4-Methoxyphenyl)benzo[d]isoxazol-3-amine (5 c)

White colored solid; mp 98-100 ${ }^{\circ} \mathrm{C}:{ }^{1} \mathrm{H}$ NMR $\left(400 \mathrm{MHz}\right.$, DMSO-d $\left.\mathrm{d}_{6}\right) ; 8.44-8.42(\mathrm{~d}, \mathrm{~J}=8.0 \mathrm{~Hz}, 1 \mathrm{H})$, 8.08-8.06 (d, J = 8.0 Hz, $1 \mathrm{H}), 8.02-8.00(\mathrm{~d}, \mathrm{~J}=8.0 \mathrm{~Hz}, 1 \mathrm{H}), 7.95-7.91(\mathrm{~m}, \mathrm{~J}=8.0 \mathrm{~Hz}, 2 \mathrm{H}), 7.71-7.67(\mathrm{~m}$, $1 \mathrm{H}), 7.26-7.24(\mathrm{~d}, \mathrm{~J}=8.0 \mathrm{~Hz}, 2 \mathrm{H}), 5.32(\mathrm{~s}, 1 \mathrm{H}), 3.88(\mathrm{~s}, 3 \mathrm{H}) ;{ }^{13} \mathrm{C}$ NMR $\left(100 \mathrm{MHz}, \mathrm{DMSO}-\mathrm{d}_{6}\right) ; 164.1$, 159.7, 152.0, 147.4, 132.2, 127.2,125.6, 123.4, 121.7, 118.9, 114.4, 113.8, 55.2; HRMS Calcd 263.0791; Found: 263.0794 $\left(\mathrm{M}+\mathrm{Na}^{+}\right)$; Anal.Calcd for $\mathrm{C}_{14} \mathrm{H}_{12} \mathrm{~N}_{2} \mathrm{O}_{2}$ : C, 69.99; H, 5.03; N, 11.66; Found: $\mathrm{C}, 70.05 ; \mathrm{H}, 5.08$; $\mathrm{N}, 11.59$.

2-(2-Chloro-4-((4-methoxyphenyl)amino)-5-methylphenyl)-2-(4-chlorophenyl)acetonitrile (5 e)

Off-white colored solid; mp 111-112 ${ }^{\circ} \mathrm{C}:{ }^{1} \mathrm{H}$ NMR (400 MHz, DMSO-d 6 ); 7.57-7.53 (m, $\left.3 \mathrm{H}\right)$, 7.51-7.42 (m, 3 H), 7.35-7.31 (m, 2 H), 7.08-7.02 (m, 2 H), $5.72(\mathrm{~s}, 1 \mathrm{H}), 5.32(\mathrm{~s}, 1 \mathrm{H}), 3.83$ (s, $3 \mathrm{H}), 2.13$ (s, $3 \mathrm{H}) ;{ }^{13} \mathrm{C}$ NMR (100 MHz, DMSO-d 6 ); 152.0, 149.8, 141.1, 140.0, 137.1, 132.4, 132.3, 132.1, 129.1, 128.6, 123.1, 120.8, 116.1, 54.99, 36.6, 17.9; HRMS Calcd 419.0688; Found: $419.0692\left(\mathrm{M}+\mathrm{Na}^{+}\right)$; Anal.Calcd for $\mathrm{C}_{22} \mathrm{H}_{18} \mathrm{Cl}_{2} \mathrm{~N}_{2} \mathrm{O}$ : C, 66.51; H, 4.57; N, 7.05; Found: C, 66.59; H, 4.52; N, 7.11.

\section{Conclusions}

In conclusion, we prepared PS-Co (BBZN) $\mathrm{Cl}_{2}$ catalyst and used it for the $\mathrm{C}-\mathrm{N}$ bond formation reaction. A series of adamantyl-tethered-amino biphenylic compounds were synthesized by new protocol. Our synthetic methodology is much improved compared to existing methodologies as the catalyst is effective, inexpensive and recyclable.

Supplementary Materials: The following are available online at http://www.mdpi.com/2073-4344/10/11/1315/s1, SI-01: Experiment Section, SI-02: Spectral characterization $\mathrm{Co}(\mathrm{BBZN}) \mathrm{Cl}_{2}$, SI-03 to14: Spectral characterization of compounds 4 a-4 1 .

Author Contributions: B.C.P., S.E.R., S.N.D. performed the organic synthesis and material characterization experiments; P.K.M., G.V., B.S.P., V.P., P.E.L. and R.K.S. supported through suggestions and guidance; K.F.-U.-R. and G.P. provided DFT calculations; B. designed the research, provided resources and wrote the manuscript. All authors have read and agreed to the published version of the manuscript.

Funding: B. thanks Council of Scientific and Industrial Research (No. 02(0291)17/EMR-II), Department of Biotechnology (BT/PR24978/NER/95/938/2017), Vision Group on Science and Technology, Government of Karnataka for funding. PEL thanks Tsinghua Berkeley Shenzhen Institute Faculty Start-Up Fund, the Shenzhen Development and Reform Commission Subject Construction Project for funding.

Conflicts of Interest: The authors declare that the research was conducted in the absence of any commercial or financial relationships that could be construed as a potential conflict of interest. 


\section{References}

1. Rasheed, S.; Rao, D.N.; Das, P. Copper-Catalyzed Inter- and Intramolecular C-N Bond Formation: Synthesis of Benzimidazole-Fused Heterocycles. J. Org. Chem. 2015, 80, 9321-9327. [CrossRef] [PubMed]

2. Wu, Z.; Huang, Q.; Zhou, X.; Yu, L.; Li, Z.; Wu, D. Synthesis of pyrido[1,2-a]benzimidazoles through a copper-catalyzed cascade C-N coupling process. Eur. J. Org. Chem. 2011, 2011, 5242-5245. [CrossRef]

3. Hesp, K.D.; Bergman, R.G.; Ellman, J.A. Rhodium-catalyzed synthesis of branched amines by direct addition of benzamides to imines. Org. Lett. 2012, 14, 2304-2307. [CrossRef] [PubMed]

4. Peng, J.; Ye, M.; Zong, C.; Hu, F.; Feng, L.; Wang, X.; Wang, Y.; Chen, C. Copper-catalyzed intramolecular C-N bond formation: A straightforward synthesis of benzimidazole derivatives in water. J. Org. Chem. 2011, 76, 716-719. [CrossRef]

5. Brain, C.T.; Steer, J.T. An improved procedure for the synthesis of benzimidazoles, using palladium-catalyzed aryl-amination chemistry. J. Org. Chem. 2003, 68, 6814-6816. [CrossRef] [PubMed]

6. Wolfe, J.P.; Wagaw, S.; Marcoux, J.; Buchwald, S.L. Rational Development of Practical Catalysts for Aromatic Carbon-nitrogen bond formation. Acc. Chem. Res. 1998, 31, 805-818. [CrossRef]

7. Tsang, W.C.P.; Zheng, N.; Buchwald, S.L. Combined C-H functionalization/C-N bond formation route to carbazoles. J. Am. Chem. Soc. 2005, 127, 14560-14561. [CrossRef] [PubMed]

8. Yang, Y.G.; Buchwald, S.L. Palladium-catalyzed amination of aryl halides and sulfonates. J. Organomet. Chem. 1999, 576, 125-146. [CrossRef]

9. Corcoran, E.B.; Pirnot, M.T.; Lin, S.; Dreher, S.D.; Dirocco, D.A.; Davies, I.W.; Buchwald, S.L.; Macmillan, D.W.C. Aryl amination using ligand-free Ni(II) salts and photoredox catalysis. Science 2016, 353, 279-283. [CrossRef]

10. Toma, G.; Yamaguchi, R. Cobalt-catalyzed C-N bond-forming reaction between chloronitrobenzenes and secondary amines. Eur. J. Org. Chem. 2010, 2010, 6404-6408. [CrossRef]

11. Ahmad, K.; Chang, C.R.; Li, J. Mechanistic investigations of Co(II)-Catalyzed C-N coupling reactions. J. Organomet. Chem. 2018, 868, 144-153. [CrossRef]

12. Ruiz-Castillo, P.; Buchwald, S.L. Applications of Palladium-Catalyzed C-N Cross-Coupling Reactions. Chem. Rev. 2016, 116, 12564-12649. [CrossRef] [PubMed]

13. Cahiez, G.; Moyeux, A. Cobalt-catalyzed cross-coupling reactions. Chem. Rev. 2010, 110, $1435-1462$. [CrossRef]

14. Sherrington, D.C. Polymer-supported metal complex alkene epoxidation catalysts. Catal. Today 2000, 57, 87-104. [CrossRef]

15. Eshwar Rao, S.; Gayathri, V. Poly(styrene-divinyl benzene)-immobilized Fe(III) complex of 1,3-bis (benzimidazolyl)benzene: Efficient catalyst for the photocatalytic degradation of xylenol orange. J. Appl. Polym. Sci. 2018, 135, 1-13. [CrossRef]

16. Fan, Q.H.; Ren, C.Y.; Yeung, C.H.; Hu, W.H.; Chan, A.S.C. Highly effective soluble polymer-supported catalysts for asymmetric hydrogenation. J. Am. Chem. Soc. 1999, 121, 7407-7408. [CrossRef]

17. Howard, I.C.; Hammond, C.; Buchard, A. Polymer-supported metal catalysts for the heterogeneous polymerisation of lactones. Polym. Chem. 2019, 10, 5894-5904. [CrossRef]

18. Annis, D.A.; Jacobsen, E.N. Polymer-supported chiral Co(salen) complexes: Synthetic applications and mechanistic investigations in the hydrolytic kinetic resolution of terminal epoxides. J. Am. Chem. Soc. 1999, 121, 4147-4154. [CrossRef]

19. Karjalainen, J.K.; Hormi, O.E.O.; Sherrington, D.C. Efficient Polymer-Supported Sharpless Alkene Epoxidation Catalyst. Molecules 1998, 3, 51-59. [CrossRef]

20. Canali, L.; Sherrington, D.C. Utilisation of homogeneous and supported chiral metal(salen) complexes in asymmetric catalysis. Chem. Soc. Rev. 1999, 28, 85-93. [CrossRef]

21. Sherrington, D.C. Polymer-supported metal complex oxidation catalysts. Pure Appl. Chem. 1988, 60, 401-414. [CrossRef]

22. Conte, V.; Floris, B. Vanadium catalyzed oxidation with hydrogen peroxide. Inorg. Chim. Acta 2010, 363, 1935-1946. [CrossRef]

23. Farzaneh, S.; Zarghi, A. Estrogen receptor ligands: A review (2013-2015). Sci. Pharm. 2016, 84, 409-427. [CrossRef] 
24. Sebastian, A.; Pandey, V.; Mohan, C.D.; Chia, Y.T.; Rangappa, S.; Mathai, J.; Baburajeev, C.P.; Paricharak, S.; Mervin, L.H.; Bulusu, K.C.; et al. Novel adamantanyl-based thiadiazolyl pyrazoles targeting EGFR in triple-negative breast cancer. ACS Omega 2016, 1, 1412-1424. [CrossRef]

25. Anusha, S.; Mohan, C.D.; Ananda, H.; Baburajeev, C.P.; Rangappa, S.; Mathai, J.; Fuchs, J.E.; Li, F.; Shanmugam, M.K.; Bender, A.; et al. Adamantyl-tethered-biphenylic compounds induce apoptosis in cancer cells by targeting Bcl homologs. Bioorg. Med. Chem. Lett. 2016, 26, 1056-1060. [CrossRef]

26. Sadashiva, M.P.; Nanjundaswamy, S.; Li, F.; Manu, K.A.; Sengottuvelan, M.; Prasanna, D.S.; Anilkumar, N.C.; Sethi, G.; Sugahara, K.; Subbegowda, K.; et al. Anti-cancer activity of novel dibenzo[b,f]azepine tethered isoxazoline derivatives. BMC Chem. Biol. 2012, 12. [CrossRef]

27. Ningegowda, R.; Shivananju, N.S.; Rajendran, P.; Basappa; Rangappa, K.S.; Chinnathambi, A.; Li, F.; Achar, R.R.; Shanmugam, M.K.; Bist, P.; et al. A novel 4,6-disubstituted-1,2,4-triazolo-1,3,4-thiadiazole derivative inhibits tumor cell invasion and potentiates the apoptotic effect of TNF $\alpha$ by abrogating NF- $\mathrm{kB}$ activation cascade. Apoptosis 2017, 22, 145-157. [CrossRef]

28. Priya, B.S.; Nanjunda Swamy, S.; Tejesvi, M.V.; Basappa; Sarala, G.; Gaonkar, S.L.; Naveen, S.; Shashidhara Prasad, J.; Rangappa, K.S. Synthesis, characterization, antimicrobial and single crystal X-ray crystallographic studies of some new sulfonyl, 4-chloro phenoxy benzene and dibenzoazepine substituted benzamides. Eur. J. Med. Chem. 2006, 41, 1262-1270. [CrossRef]

29. Anusha, S.; Anandakumar, B.S.; Mohan, C.D.; Nagabhushana, G.P.; Priya, B.S.; Rangappa, K.S. Preparation and use of combustion-derived $\mathrm{Bi} 2 \mathrm{O} 3$ for the synthesis of heterocycles with anti-cancer properties by Suzuki-coupling reactions. RSC Adv. 2014, 4, 52181-52188. [CrossRef]

30. Rakesh, K.S.; Jagadish, S.; Vinayaka, A.C.; Hemshekhar, M.; Paul, M.; Thushara, R.M.; Sundaram, M.S.; Swaroop, T.R.; Mohan, C.D.; Sadashiva, M.P.; et al. A new ibuprofen derivative inhibits platelet aggregation and ros mediated platelet apoptosis. PLoS ONE 2014, 9, e2718. [CrossRef]

31. Nirvanappa, A.C.; Mohan, C.D.; Rangappa, S.; Ananda, H.; Sukhorukov, A.Y.; Shanmugam, M.K.; Sundaram, M.S.; Nayaka, S.C.; Girish, K.S.; Chinnathambi, A.; et al. Novel synthetic oxazines target NF- $\mathrm{B}$ in colon cancer in vitro and inflammatory bowel disease in vivo. PLoS ONE 2016, 11, e0163209. [CrossRef] [PubMed]

32. Tan, B.Y.H.; Teo, Y.C. Efficient cobalt-catalyzed C-N cross-coupling reaction between benzamide and aryl iodide in water. Org. Biomol. Chem. 2014, 12, 7478-7481. [CrossRef] [PubMed]

33. Moselage, M.; Li, J.; Ackermann, L. Cobalt-Catalyzed C-H Activation. ACS Catal. 2016, 6, 498-525. [CrossRef]

34. Ibrahim, H.; Bala, M.D. Air stable pincer (CNC) N-heterocyclic carbene-cobalt complexes and their application as catalysts for C-N coupling reactions. J. Organomet. Chem. 2015, 794, 301-310. [CrossRef]

35. Yanai, T.; Tew, D.P.; Handy, N.C. A new hybrid exchange-correlation functional using the Coulomb-attenuating method (CAM-B3LYP). Chem. Phys. Lett. 2004, 393, 51-57. [CrossRef]

36. Frisch, M.J.; Trucks, G.W.; Schlegel, H.B.; Scuseria, G.E.; Robb, M.A.; Cheeseman, J.R.; Scalmani, G.; Barone, V.; Mennucci, B.; Petersson, G.A.; et al. Gaussian 09, Revision D.01; Gaussian Inc.: Wallingford, CT, USA, 2009.

Publisher's Note: MDPI stays neutral with regard to jurisdictional claims in published maps and institutional affiliations.

(C) 2020 by the authors. Licensee MDPI, Basel, Switzerland. This article is an open access article distributed under the terms and conditions of the Creative Commons Attribution (CC BY) license (http://creativecommons.org/licenses/by/4.0/). 